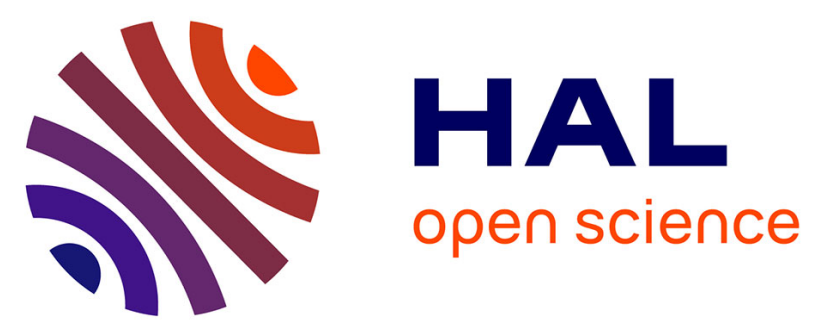

\title{
A unique novel reptilian paramyxovirus, four atadenovirus types and a reovirus identified in a concurrent infection of a corn snake () collection in Germany
}

Maha Diekan Abbas, Rachel E. Marschang, Volker Schmidt, Astrid Kasper, Tibor Papp

\section{To cite this version:}

Maha Diekan Abbas, Rachel E. Marschang, Volker Schmidt, Astrid Kasper, Tibor Papp. A unique novel reptilian paramyxovirus, four atadenovirus types and a reovirus identified in a concurrent infection of a corn snake () collection in Germany. Veterinary Microbiology, 2011, 150 (1-2), pp.70. 10.1016/j.vetmic.2011.01.010 . hal-00687335

\section{HAL Id: hal-00687335 https://hal.science/hal-00687335}

Submitted on 13 Apr 2012

HAL is a multi-disciplinary open access archive for the deposit and dissemination of scientific research documents, whether they are published or not. The documents may come from teaching and research institutions in France or abroad, or from public or private research centers.
L'archive ouverte pluridisciplinaire HAL, est destinée au dépôt et à la diffusion de documents scientifiques de niveau recherche, publiés ou non, émanant des établissements d'enseignement et de recherche français ou étrangers, des laboratoires publics ou privés. 


\section{Accepted Manuscript}

Title: A unique novel reptilian paramyxovirus, four atadenovirus types and a reovirus identified in a concurrent infection of a corn snake (Pantherophis guttatus) collection in Germany

Authors: Maha Diekan Abbas, Rachel E. Marschang, Volker

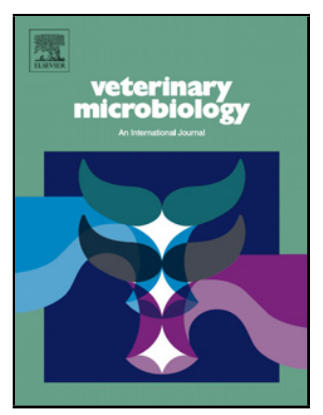

Schmidt, Astrid Kasper, Tibor Papp

PII:

S0378-1135(11)00014-9

DOI: doi:10.1016/j.vetmic.2011.01.010

Reference: $\quad$ VETMIC 5148

To appear in: $\quad$ VETMIC

Received date: $\quad 20-8-2010$

Revised date: $\quad$ 23-12-2010

Accepted date: $\quad$ 10-1-2011

Please cite this article as: Abbas, M.D., Marschang, R.E., Schmidt, V., Kasper, A., Papp, T., A unique novel reptilian paramyxovirus, four atadenovirus types and a reovirus identified in a concurrent infection of a corn snake (Pantherophis guttatus) collection in Germany, Veterinary Microbiology (2010), doi:10.1016/j.vetmic.2011.01.010

This is a PDF file of an unedited manuscript that has been accepted for publication. As a service to our customers we are providing this early version of the manuscript. The manuscript will undergo copyediting, typesetting, and review of the resulting proof before it is published in its final form. Please note that during the production process errors may be discovered which could affect the content, and all legal disclaimers that apply to the journal pertain. 
1 A unique novel reptilian paramyxovirus, four atadenovirus types and a reovirus identified in a concurrent infection of a corn snake (Pantherophis guttatus) collection in Germany

Maha Diekan Abbas ${ }^{\mathrm{a}}$, Rachel E. Marschang ${ }^{\mathrm{a}}$, Volker Schmidt ${ }^{\mathrm{b}}$, Astrid Kasper ${ }^{\mathrm{c}}$, Tibor Papp $^{\mathrm{a}, \mathrm{d}, *}$

anstitut für Umwelt- und Tierhygiene, University of Hohenheim, Stuttgart, Germany; ${ }^{\mathrm{b}}$ Bird and Reptile Clinic, University of Leipzig, Leipzig, Germany; 'Praxis for Small Animals, Birds and Exotics, Amberg-Raigering, Germany; 'Veterinary Medical Research Institute of the Hungarian Academy of Sciences, Budapest, Hungary

*Corresponding author: Tel.: +49 711459 22446; +36 1 467-4060; Fax: +49 711459 22431. +36 1 467-4076; E-mail address: kabafalvi@googlemail.com

\section{Abstract}

In 2009, 26 clinical samples (organs and oral/cloacal swabs) from a total of 24 corn snakes (Pantherophis guttatus) from a single owner were sent to our laboratory to be tested for the presence of viruses. Paramyxoviruses (PMV), adenoviruses (AdV) and reoviruses were detected by RT-PCR, PCR and virus isolation methods. Three snakes were infected with all three viruses at the same time, while two other snakes had a double infection (PMV and reo, AdV and reo) and nine other snakes had a single infection with any of the three viruses. No viruses were detected in 10 animals. All isolated reoviruses were identical to one another and to the reptilian orthoreovirus isolate 55-02 in the partial RNA dependent RNA polymerase (RDRP) gene sequence. AdV partial polymerase sequences represented four different types, one 
1 of which was first described here: most similar to SnAdV-1, while the other three

2 were identical to known types: SnAV-1, -2 and -3. However, the detected single PMV

3 differed distinctly from described reptile PMV and was a new type. According to

4 partial $\mathrm{L}$ gene, $\mathrm{HN}$ gene and $U$ gene sequences it may be the first described 5 representative of a third squamatid PMV cluster: "group C" within the proposed 6 reptilian PMV genus "Ferlavirus". Nucleotide identity values for the $L$ gene of the new $7 \quad$ PMV compared to group A viruses range between $76.5-80.3 \%$, and between 80.5 $81.2 \%$ compared to group B viruses. For the $\mathrm{HN}$ gene, these values were similar: $78.2-80 \%(A)$ and $79.9-80.5 \%(B)$ and somewhat lower for the $U$ gene: $72.7-75.4 \%$ (A) and $69.7-70 \%$ (B). No reports on the prevalence of concurrent viral infection in captive snake populations have been published so far. The possibility of concurrent infection with several different viruses and subsequent consequences for animal health should be kept in mind when testing reptile samples for viruses.

\section{Introduction}

17 Paramyxoviruses (PMV) have been isolated from several reptiles, mainly snakes, and have been characterized morphologically, immunologically and/or molecular biologically (Blahak, 1995; Richter et al., 1996; Ahne et al., 1999; Franke et al., 2001; Kindermann et al., 2001; Marschang et al., 2009).

21 The first recorded outbreak of PMV occurred in 1972 in a snake farm in Switzerland 22 in common lancehead vipers (Bothrops atrox) (Fölsch and Leloup, 1976). The causative agent was named Fer de Lance virus (FDLV) and is regarded as the type species for reptilian PMV (Clark et al., 1979). Recently, the complete genome of FDLV has been fully sequenced (Kurath et al., 2004). This genome has a unique gene $(U$ gene) that is absent in other PMVs, which encodes a short protein of 
1 unkown function. This feature together with the results of phylogenetic calculations

2 supports the classification of FDLV in a new proposed genus "Ferlavirus" of the

3 Paramyxovirinae subfamily. PMV have been detected in many different snake

4 species from all major families including Boidae, Elapidae, Colubridae, and

5 Viperidae. These viruses were first named ophidian (snake) paramyxoviruses

6 (OPMV) (Essbauer and Ahne, 2001), but have since also been described in lizards

7 and tortoises (Marschang et al., 2009; Papp et al., 2010b). Reptilian PMV are

8 considered one of the most important pathogens of snakes and have been isolated

9 from both private and zoological collections (Jacobson, 2007). They have also been described as emerging infectious diseases which may endanger wildlife (Daszak et 11 al., 2000; Jacobson, 1993; Azevedo et al., 2001). Clinical signs observed in PMV 12 infected snakes most commonly involve the respiratory tract, but central nervous system (CNS) disease is also regularly observed (Jacobson, 2007). Phylogenetic analysis of partial gene sequences of PMV isolated from snakes but also from lizards and a tortoise revealed that there are at least two squamatid lineages (groups) both containing snake and lizard isolates, whereas the sole tortoise PMV isolate from a Hermann's tortoise (Testudo hermanni) clusters as an ancient, separate lineage of the proposed new reptilian PMV genus "Ferlavirus" (Marschang et al., 2009). An additional study detected a squamatid PMV in a diseased leopard tortoise (Papp et al., 2010b), demonstrating the wide host range of some of these viruses.

21 Reovirus infections have been reported in several species of reptiles including 22 snakes (Ahne et al., 1987; Blahak and Göbel, 1991; Blahak, et al., 1995; Jacobson, 23 1986), lizards (Ahne at al., 1987; Drury et al., 2002; Marschang et al., 2002;

24 Marschang and Papp, 2010), and tortoises (Drury et al., 2002; Marschang and Chitty, 2004). Clinical signs associated with reovirus infections have been pneumonia and 
1 neurologic problems that may appear similar to PMV infections (Wellehan et al., 2 2009).

3 The number of reports of adenovirus (AdV) infections in reptiles is increasing,

4 apparently due to the growing popularity of reptiles as pets (Essbauer and Ahne, 2001) and to sensitive diagnostic methods (Wellehan et al., 2004). AdV infections

6 have been reported in several reptile species including crocodiles, snakes, and 7 lizards (Frye et al., 1994; Jacobson and Gardiner, 1990; Kinsel et al., 1997; Ramis et al., 2000). In these species, adenovirus infection was considered the cause of gastroenteritis, hepatitis, nephritis, pneumonia and encephalitis (Frye et al., 1994; Helstab and Bestetti, 1984; Schumacher et al., 1994). The single fully sequenced

11 reptilian isolate is from a corn snake (Pantherophis guttatus) (Farkas et al., 2002; 2008). This snake adenovirus type 1 (SnAdV-1) represents the supposed reptilian lineage of the Atadenovirus genus. Further squamatid AdVs (including new snake types) have been partially sequenced and found to belong to the same genus (Wellehan et al., 2004; Garner et al., 2008; Papp et al., 2009a; Benkő et al., 2006; Pénzes et al., 2010). Interestingly, unlike PMVs, the recently described chelonian AdVs cluster separate from the squamatid $A d V s$, either to the supposed amphibian lineage Siadenovirus genus (Rivera et al., 2009) or outside of the five accepted genera of the family Adenoviridae (Farkas et al., 2009; Doszpoly and Harrach, personal communication; Wellehan et al., personal communication).

21 During routine diagnostic testing for reptilian viruses we found a concurrent ongoing 22 infection with all three above described viruses in a collection of corn snakes including a snake that died suddenly showing dispnoe and vomitus prior to exitus. The survivors showed no specific symptoms. A follow-up study was performed in the animals from two consecutive collections for over 5 months, before they were finally dispersed. Detected viruses were partially sequence characterized, and most of the 
1 viruses were also isolated on permanent cell lines. The PMV detected in these corn

2 snakes is new to science, and seems to be the first described representative of a

3 third major squamatid PMV group.

6 Samples

7 In January 2009, a dead juvenile female corn snake (Pantherophis guttatus) (Lab.

8 No. 6/3/09) was dissected at the Bird and Reptile Clinic, University of Leipzig,

9 Leipzig, Germany. Its body weight was $4 \mathrm{~g}$ and the head-cloaca length $29 \mathrm{~cm}$. Prior to death, the snake had dyspnoea and vomitus. Gross necropsy showed cachexia.

11 The stomach was moderately filled with brown pasty content, the gut was empty and 12 no macroscopic lesions were observed. Histopathologically the only finding was hyperplasia of melanophagocytes in the liver, while other organs showed advanced autolysis. According to the clinical symptoms, the hyperplasia of melanophagocytes, the juvenile age and the history of ananother death in the snake collection, a viral disease was suspected. Samples of lung, kidney, and intestine were sent to the University of Hohenheim, Stuttgart, Germany for virus detection. One month later, 13 young corn snakes (body weight: 7-30 g) remaining in the possession of the same owners were swabbed (oral and cloacal) and tested (Lab. No. 14/1/09 to 14/13/09). Later, without further notice the owner dispersed the stock (some were reported to 21 have died afterwards) and established a new snake collection. At this point - five months after the first tests - these 10 animals (Lab. No. 54/1/09 to 54/10/09) were also swabbed and tested. All together 26 clinical diagnostic samples including 3 organs and 23 oral and cloacal swabs from a total of 24 corn snakes of two consecutive stocks kept at the same enclosure of one owner were sent to our laboratory and tested for the presence of PMV, AdV, and reoviruses (Table 1). 
1 Tissue samples or swabs were immersed in $3 \mathrm{ml}$ Dulbecco's modified Eagle's

2 medium (DMEM) (Biochrom AG, Berlin, Germany) supplemented with antibiotics for

3 further processing.

Virus isolation

6 Isolation of viruses was attempted from all samples on Russell's viper heart cells

7 (VH-2, ATCC: CCL-140) and iguana heart cells (IgH2, ATCC, CCL-108). Samples in

8 DMEM were sonicated for destruction of cells and suspension of viruses. The samples were then centrifuged at $3000 \mathrm{xg}$ for $10 \mathrm{~min}$. for the removal of cell-debris and bacteria, then $200 \mu \mathrm{l}$ of the homogenate was inoculated onto medium-free, approximately $70 \%$ confluent cell monolayers in $30 \mathrm{~mm}$ diameter Cellstar $^{\circledR}$ tissue

12 culture dishes (Greiner Bio-One GmbH, Frickenhausen, Germany). After incubating 13 for $2 \mathrm{~h}$ (at $28{ }^{\circ} \mathrm{C}, 5 \% \mathrm{CO}_{2}$ ) $2 \mathrm{ml}$ nutrient medium (DMEM supplemented with $2 \%$ foetal calf serum, $1 \%$ non-essential amino acids and antibiotics $(200 \mathrm{U} / \mathrm{ml}$ penicillin$\mathrm{G}, 380 \mathrm{U} / \mathrm{ml}$ streptomycin-sulfate, $6.4 \mathrm{U} / \mathrm{ml}$ gentamycinsulfate and $0.5 \mu \mathrm{g} / \mathrm{ml}$ amphotericin-B) were added to each dish. Cells were examined for the presence of cytopathic effects (CPE) approximately every 3 days with an inverted light microscope (Leitz, Weitzlar, Germany), dishes were frozen when extended CPE was seen. Dishes showing no CPE were frozen after 2 weeks of incubation for blind passaging. Two additional passages were performed from each dish after a freeze and thaw cycle and low speed centrifugation. RNA and DNA were prepared from the cell culture supernatant as described below for further identification and characterization of isolates.

In the case of mixed virus isolates, a 10 fold serial dilution of the supernatant was 
1 plate (Becton Dickinson Labware, Franklin Lakes, USA) were inoculated in parallel in

2 order to separate the different viruses (end-point dilution, Reed and Muench, 1938).

3 To determine whether virus isolates were enveloped, chloroform treatment was

4 performed by mixing chloroform and virus suspension 1:10, followed by shaking on a

5 vortex for $1 \mathrm{~h}$ and centrifugation at $10.000 \times \mathrm{g}$ for $10 \mathrm{~min}$. The supernatant was then

6 diluted 1:10 in maintenance medium and inoculated into tissue culture dishes as

7 described. Infectious cell culture supernatant without chloroform treatment was

8 inoculated parallel into tissue culture dishes. Plague purification assay was also

9 performed, as described by Bijlenga and Duclos (1989) with some modifications.

10 Nutrient medium (see above) was prepared with an additional $1 \%$ of agar-agar

11 (Merk, Darmstadt, Germany). Tissue culture dishes were infected with the mixed

12 virus isolate, and after two hours of incubation $2 \mathrm{ml}$ of this semi-solid medium was

13 added. Dishes were incubated at $28 \stackrel{\circ}{\mathrm{C}}, 5 \% \mathrm{CO}_{2}$ for 3 days, microscopic agar-plaque samples were collected randomly using pipette tips and placed separately in $500 \mu \mathrm{l}$ DMEM supplemented with a $2 x$ concentration of antibiotics. Samples were then sonicated in an ice bath (Bandelin electronics, Berlin, Germany, $40 \mathrm{KHz}$ ) for 5 minutes and re-inoculated onto one day-old tissue culture dishes and incubated for ten days.

RNA and DNA extraction.

RNA was prepared from $300 \mu \mathrm{l}$ of the sonicated clinical samples and virus isolate supernatants using the guanidinium isothiocyanate method described by Boom et al. (1990) and resuspended in $75 \mu$ l of RNase free water.

DNA extraction of the sonicated clinical samples and virus isolate supernatants (both from $200 \mu \mathrm{l}$ ) was carried out using the DNeasy ${ }^{\circledR}$ Blood and Tissue Kit (Quiagen 
$1 \mathrm{GmbH}$, Hilden, Germany) following the protocol of the manufacturer in a final elution

2 volume of $100 \mu$ l.

$P C R / R T-P C R$ and sequencing

A nested RT-PCR targeting a portion of the $L$ gene of ophidian PMV was carried out using the primers described by Ahne et al. (1999) in $25 \mu$ reaction mixtures. The RTPCR targeting portion of $\mathrm{HN}$ gene was performed as for $\mathrm{L}$ gene using primers $\mathrm{F} 1$ and R2 (Ahne et al., 1999) in the first round, and HN-cons Fwd-in and HN-cons Rev-in (Marschang et al., 2009) in the second round. The RT PCR targeting the complete ORFs of the $\mathrm{U}$ gene was carried out similarly using U-cons Fwd-out and U-cons Rev-

11 out in the first round, and U-cons Fwd-in and U-cons Rev-in the second round 12 (Marschang et al., 2009). The chemistry used for all PCRs is decribed in the latter paper.

14 For reovirus detection, a nested RT-PCR targeting a portion of the RNA-dependent RNA polymerase (RDRP) gene was carried out as described by Wellehan et al., (2008). The primers $1607 \mathrm{~F}$ and $2608 \mathrm{R}$ were used for the RT and first round PCR reactions, the second round of PCR amplification was carried out using the primers 2090F and 2200R.

Nested AdV PCRs were carried out as described by Papp et al. (2009) using the primers originally described by Wellehan et al. (2004). The PCR protocol was

21 optimized for some samples to remove unspecific bands by raising the annealing 22 temperature to $50^{\circ} \mathrm{C}$ and adding a total of $2 \mathrm{mM} \mathrm{MgCl}_{2}$ in the second round.

23 Products of all PCR protocols were separated on 1.5\% agarose gels (Bioenzym, 24 Oldendorf, Germany) in TAE puffer containing $0.5 \mathrm{mg} / \mathrm{ml}$ ethidium-bromide and 25 visualised under $320 \mathrm{~nm}$ UV light. Gel purified PCR amplicons (Invisorb Spin DNA 26 Extraction Kit; Ivitek GmbH, Berlin, Germany) were sequenced directly using a Big- 
1 Dye terminator kit v.1.1 and analysed on an $A B I$ prism 310 automated DNA

2 sequencer (both Applied Biosystems, Foster City, USA).

4 Analysis of sequences

5 Raw sequences were processed by the ABI Sequence Analysis Programme 5.1.1

6 (Applied Biosystems, Foster City, USA) then edited, assembled and compared using 7 the STADEN Package version 2003.0 Pregap4 and Gap4 programmes (Bonfield et 8 al., 1995). The sequences were compared to data in GenBank (National Center for

9 Biotechnology Information, Bethesda, USA) online (www.ncbi.nih.gov) using BLASTN and BLASTX options. Multiple alignments of nucleotide sequences were performed with ClustalW algorithm of the BioEdit Sequence Alignment Editor 12 programme (Hall, 1999). This alignment was further used for phylogenetic calculations in the PHYLIP program Package version 3.6. (Felsenstein, 1989) comparing parsimony, maximum-likelihood, and distance based methods to obtain an optimal tree. Bootstrap analysis of 100 replicates was carried out.

\section{Results}

In this study we have investigated 26 organs and oral/cloacal swabs originating from 24 corn snakes of two successive stock of a single owner and were able to detect PMV by PCR in the 7 snakes of the fist stock, and AdVs from 3 snakes both in the

21 first and second stocks. Reoviruses were successfully isolated from 7 \& 2, PMV from $2 \& 0$ and $\mathrm{AdV}$ from $2 \& 0$ snakes of the first \& second stock respectively (Table 1 ).

(RT-)PCR results

PMV L gene nested RT-PCR gave a positive signal (566 bp product) with the kidney and intestine of the dead animal and six swabs of the surviving snakes from the $1^{\text {st }}$ 
1 collection (50\%) (Table 1 ), but none from the $2^{\text {nd }}$ collection. From the L-gene positive

2 samples each (50\% of group one) were positive in the HN gene nested RT-PCR (399

3 bp), and all but one (sample "14/8/09", 42.8\% positive of group one) using the $U$

4 gene nested RT-PCR (640 bp). The homologous PMV partial gene sequences found

5 in different samples were identical to one another, and represent a new reptilian PMV

6 (assigned name: PanGut-GER09) (Fig. 1 and Fig S-1). The PanGut-GER09 partial

7 gene sequences have been submitted to GenBank and assigned the accession numbers: HQ148084 to HQ148087.

AdVs were detected from the diagnostic samples using consensus nested PCR (product size: $320 \mathrm{bp}$ ) in 6 animals altogether (25\%), 3 from the $1^{\text {st }}$ group $(21.4 \%)$ (Table 1). The AdV from the kidney and intestine of the dead snake (6/3/09) had a partial polymerase sequence identical to the GenBank (FJ012163) snake adenovirus type 2 (SnAdV-2) sequence. Two surviving snakes of this $1^{\text {st }}$ collection $(14 / 2 / 09$ \& 14/3/09) that were also identified with AdV infection by PCR revealed two different viruses based on their partial polymerase sequences with $100 \%$ and $93 \%$ identity respectively to the SnAdV-1 (DQ106414). This latter, new sequence is identical to that of a recently reported tiger python (Python molurus) AdV isolate (Papp et al., 2009b; Romanova et al., 2010), a supposed new serotype of the SnAdV-A virus species, and has been submitted to GenBank with an accession number: HQ148088. Three animals of the $2^{\text {nd }}$ collection $(30 \%)$ were AdV positive. The sequencing revealed three different viruses: beside the above mentioned SnAdV-1 (54/4/09) and SnAV-2 (54/6/09), a third type, identical in its partial polymerase sequence to the SnAV-3 (FJ012164) was also detected in a snake (54/1/09).

Reoviruses were not detected directly from the diagnostic samples using the nested RT-PCR targeting the RNA dependent RNA polymerase (RDRP). 
2 Adenoviruses were isolated in two cases (14.3\%), once from the intestine of the dead

\section{Isolation of viruses} snake $(6 / 3 / 09)$ and from a swab taken from a survivor (14/2/09) in the first collection (Table 1). Observed cytopathic effects (CPE) with rounding and detachment of some cells (Fig S-1b) were typical of AdV. Paramyxoviruses were isolated from the kidney and intestine of the dead animal and from the swab of the same survivor as above. Typical CPE of giant fusion cells (syncitia) was observed. Reoviruses were isolated from a total of 9 snakes (37.5\%), including all three organs of the dead snake and six survivors of the first collection, as well as two swabs from the second collection (Table 1). The cytopathic effect (CPE) caused by the PMV and reoviruses were both characterized by cytolysis and giant syncytial cell formation. Verification of the presence of reoviruses in cell culture supernatant by consensus nested RT-PCR (110 bp) was positive in all cases. All isolated reoviruses had identical partial RDRP genes sequences to one another and to the reptilian GenBank carpet python (Morelia spilota) orthoreovirus isolate 55-02 (GenBank accession No. E4309703).

In both cases of AdV isolation, PMV and reoviruses were also present in the isolates. The PMV isolates are easily overgrown with reovirus, yet the presence of PMV was verified by $L, U$, and $H N$ gene RT-PCR amplification of PMV RNA from the cell culture supernatant. Using the end-point dilution method followed by chloroform treatment pure AdV was obtained from the 14/2/09 sample. Using an end-point dilution method followed by a plaque purification assay, a pure PMV isolate was obtained from the same sample, as verified by verified via (RT-)PCR. The PMV grew slowly in cell culture, with gradual development of a specific CPE with small syncytial cell formation (on day 10 post inoculation). In the case of $6 / 3 / 09$, following chloroform treatment and end-point dilution of the isolate, the AdV specific CPE was still obscured by the syncitia of the fusogenic reovirus and it could not be isolated in a 
1 pure culture using the methods above. Verification of the presence of AdV in cell

2 culture was carried out by PCR amplification of AdV specific DNA in cell culture

3 supernatant. Sequencing of the amplicons verified that there are two different AdV

4 types (SnAdV-1 and -2) in the two isolates. All of the above listed isolates could be

5 further passaged on homologous cells.

6

7 Infection rate

8 Summarizing the PCR and virus isolation results, the following infection rates were observed. Three snakes $(21.4 \%)$ of the $1^{\text {st }}$ collection $(6 / 3 / 09,14 / 2 / 09 \& 14 / 3 / 09)$ were identified with a triple viral infection with reoviruses, PMV, and AdV. One snake

$11(7.1 \%)$ in this collection $(14 / 6 / 09)$ had a double infection with a reovirus and PMV, 12 three snakes (14/5/09, 14/10/09 \& 14/13/09) had single infections with a reovirus and three further ones $(14 / 8 / 09,14 / 11 / 09 \& 14 / 12 / 09)$ had a single infection with PMV. The remaining four $(28.6 \%)$ of the 14 tested animals of the $1^{\text {st }}$ collection were negative in all virus detection tests (Table 1 ). In the case of the $2^{\text {nd }}$ collection one snake (54/4/09) (10\%) had a double infection with a reovirus and AdV, two snakes (54/1/09 \& 54/6/09) (20\%) were infected with only AdV and one (54/3/09) with only reovirus. An additional six (60\%) animals from this group were tested and found negative in the virus diagnostic tests.

Sequence analysis of new reptilian PMV

$\mathrm{L}, \mathrm{HN}$, and $\mathrm{U}$ gene partial sequence data revealed a novel PMV type (PanGutGER09) in seven animals of the first snake collection. This virus is nearly equally distant from the previously described "A" and "B" squamatid (snake and lizard) rPMV groups (Marshang et al., 2009). Nucleotide identity values for the new partial L gene 
$181.2 \%$ compared to group "B" ones. The identity value compared to the single

2 tortoise isolate is $73.8 \%$.

3 For the HN gene, these values are similar: $78.2-80 \%$ ("A") and $79.9-80.5 \%$ ("B") and

4 somewhat lower for the $U$ gene (including non-coding regions): $72.7-75.4 \%$ (“ $A$ ") and

$5 \quad 69.7-70 \%$ ("B"). Phylogenetic calculations (Fig. 1) based on the three partial gene

6 sequences show that all rPMV form a single monophyletic cluster, representing the

7 proposed new "Ferlavirus" genus. Within this genus the earlier described tortoise

8 isolate and the "A" and "B" squamatid PMVs form separate groups. The novel

9 PanGut-GER09 virus clusters with moderate bootstrap values either to the "B" group

10 (L gene, Fig. 1a), or to group "A" (HN \& U gene, Fig. 1bc), as a sister taxon.

11 Alignments are shown in Figures S1-2.

12 In the transcriptional analysis of the squamatid (or reptile) PMV specific gene of unknown function ( $\mathrm{U}$ gene) both earlier described consensus reading frames (ORF-1 \& -2) (Kurath et al., 2004; Marschang et al., 2009) were identified in the new isolate (Fig S1). The putative protein coded by ORF-1 has a predicted length of 82 aa 16 (suppl.: Fig. S2c), whereas ORF-2 encodes a 144 aa protein (suppl: Fig. 2d), 1 or 2 17 aa longer than those found in rPMV of group B or A respectively. Nucleotide identity values of the overlapping presumed coding regions of the $U$ gene were comparable to those seen in the $\mathrm{L}$ and HN gene partial CDS. Yet unlike the latter two genes, the $\mathrm{U}$ gene putative ORFs of the new isolate had a distinctly higher similarity to the group "A" viruses than to group "B" ones: 85.9-86.7\% (“A”) / 77.1-77.9\% ("B") for ORF1 or 81.9-83.5\% ("A") / 78.4-78.6\% ("B") for ORF-2. Additionally, repeated sequencing verified that there is a single nucleotide variation at position 383 (Fig. S1/c) of the $U$ gene sequence, resembling four $(6 / 3 / 09,14 / 2 / 09,14 / 3 / 09,14 / 11 / 09)$ and two $(14 / 6 / 09,14 / 12 / 09)$ samples respectively of the detected six cases, and coding a silent mutation of ORF-2. 


\section{Discussion}

3 The purchase of new reptiles is associated with a particularly high risk of introducing

4 disease into a collection. Viral infections such as inclusion body disease (IBD) and $5 \quad$ PMV often lead to devastating disease when they are transmitted to healthy snakes

6 (Pasmans et al., 2008). Some studies demonstrate that there is a significant risk of 7 hidden infectious diseases including PMV, inclusion body disease (IBD) and some bacterial infections in apparently healthy snake collections (Pees et al., 2010). Basic veterinary health checks and quarantine measures are of great importance to minimize the risk of infection among newly established snake groups.

11 In the current study, multiple viral infections were detected in captive corn snakes.

12 The pathogenic role of the concurrent viral infection in the present case could not be fully clarified as only limited data were made available, and the owner dispersed the population without further notice soon after our second positive tests. We presume that mixing of previously untested animals of uncertain origins to form a new breeding population might be the source of infection in the $1^{\text {st }}$ collection of this study, 17 while in the case of the $2^{\text {nd }}$ collection after dispersing the $1^{\text {st }}$ snake group, inappropriate disinfection of the terrariums could also be a factor for transmitting viral infection into the newly introduced animals, as the same types of non-enveloped viruses (reo-, AdV) were detected in these animals as before, whereas the

21 environmentally less stable PMV was no longer present. Detecting a further type of 22 virus (SnAdV-3) in the $2^{\text {nd }}$ collection might be due to previous infection in one of the new animals, leading to the introduction of this type into the newly formed collection as a result of a lack of screening and entry examinations. In addition to quarantine and disinfection procedures, screening and entry examinations are also of great 
1 importance for detecting the prevalence of such infectious diseases (Pees et al.,

2 2010).

3 Viral polymerases are often highly conserved, as they are essential for viral function.

4 They are therefore often good targets for viral diagnostic assays. In the present paper we have used earlier described nested (RT-) PCRs targeting the polymerase genes to detect infection with reoviruses, PMV, and AdV (Wellehan et al., 2008; Ahne et al., 1999; Wellehan et al., 2004) from snake tissue samples and swabs. We have also used classical virus isolation method on permanent reptilian cell lines, and two further PCRs for the characterization of PMV (Marschang et al., 2009). Considering the results and in consensus with earlier papers (Marschang et al., 2009; Papp et al., 2010a) we can state that the nested RT-PCR targeting the L-gene (Ahne et al., 1999) is the most sensitive method currently available and the recommended procedure for basic diagnostic testing for PMV detection. A nested PCR targeting the polymerase gene (Wellehan et al., 2004) is also the most sensitive assay to date for the detection of AdV. However, in the case of reoviruses, the consensus nested RT-PCR targeting the RDRP gene (Wellehan et al., 2008) is less sensitive than the virus isolation method (Table 1, see also Marschang and Papp, 2010), although it provides a useful tool for the initial characterization of these viruses. All reoviruses detected in the current study using the RT-PCR were from RNA extracts of cell culture isolates. No reoviruses were detected in original samples prior to isolation on cell culture. Optimization trials along with designing new primers might be necessary to increase the efficiency of this RT-PCR protocol. Reoviruses are commonly described in reptiles, mostly in snakes (Jacobson, 2007). Previous studies have shown that reoviruses isolated from reptiles can differ from one another both serologically and molecularly (Blahak and others 1995, Wellehan et al., 2009; Pees et al., 2010), however, in the present study all isolated reoviruses 
1 from nine snakes (including tissues of a dead one, seven survivors of the $1^{\text {st }}$

2 collection and two snakes in the $2^{\text {nd }}$ collection, Table 1) were identical to one another

3 and $100 \%$ identical to the reptilian orthoreovirus isolate 55-02 (E4309703),

4 suggesting a single source for the infection.

5 The AdV sequences detected in six snakes from the two collections, on the other

6 hand, could be divided into four distinct types, representing the previously described

7 SnAdV-1, -2 and -3 types (Farkas et al., 2002; 2008; Garner et al., 2008) and an

8 additional SnAdV-1-like (93\% id.) virus of the same species: SnAdV-A (Papp et al.,

9 2009b). This novel virus type is to be better characterized in a separate publication

10 together with similar novel types (Romanova et al., 2011). This finding is of great

11 interest as it contributes new aspects to the postulated coevolution theory of

12 adenoviruses (Harrach, 2000; Davison et al., 2003). The present paper shows that

13 the same corn snake species (Pantherophis guttatus, Colubridae) can be infected

14 with 4 different atadenovirus types (3 AdV species) that were earlier detected in other

15 colubrid, boid, pythonid or viperid snake species.

16 Despite the numerous detections of reptilian AdV by electron microscopy and PCR,

17 there are very few reported cases in which the virus was successfully isolated

18 (Juhász and Ahne, 1992; Ogawa et al., 1992; Papp et al., 2009a). Partial sequence data of the different snake isolates suggest that these are the same type: SnAdV-1, which was also isolated in this study. However, this study is the first report on the

21 isolation of the proposed type 2 snake $\mathrm{AdV}$ in cell culture (6/3/09 intestine, mixed 22 with reo- \& PMV). This snake AdV type 2 has been identified previously in the USA 23 (Garner et al., 2008), Germany (Papp et al., 2009a) and Hungary (Farkas, 24 unpublished data) by PCR. Continuous efforts are being made to obtain a pure 25 culture of this AdV. 
1 PMV infections have been involved in high mortality diseases in snake collections

2 (Fölsch and Leloup, 1976; Jacobson, 1986). A recent publication reports concurrent

3 infection with several distinct PMV in a single snake or group of snakes (Papp et al.,

4 2010a) during one outbreak, yet all earlier papers (Ahne et al., 1999; Franke et al.,

5 2001) identified the same PMV in animals of the same population or outbreak. In the

6 present study, sequencing of three gene portions revealed a single novel unique

$7 \quad$ rPMV in seven (one dead and six living) snakes from the $1^{\text {st }}$ collection, which could

8 be isolated first in a mixed, then in pure culture.

9 The first molecular based ( $\mathrm{L}$ and $\mathrm{HN}$ gene) classification of reptilian PMV by Ahne and co-authors (1999) described two distinct "subgroups" with very low inner

11 variance, called "a" and "b" and a set of more variable intermediate isolates. Later,

12 Franke and co-authors (2001) described three clusters (A, B and C) on their L gene phylogenetic tree. Unfortunately, this latter publication did not include sequences from the earlier paper in the comparison, thus the denominations of their clusters do not refer to those of the subgroups ("cluster A" corresponded to the earlier "subgroup b", "cluster B" to the "intermediate isolates", and "cluster C" to the earlier "subgroup a"). This discrepancy in the names was resolved in recent publications by our research group (Marschang et al., 2009). Considering the seniority rule in nomenclature, and the high bootstrap monophyletic clusters of the $L, H N$ and $U$ gene trees, a revised grouping for the squamatid rPMV was suggested: A "sensu lato" 21 group "A" contained the previous "subgroup a" and the old and new "intermediate 22 isolates", while the "sensu lato" group "B" those from "subgroup b" and similar squamatid PMVs. The use of "C" as a denomination for any group was omitted. A single tortoise isolate was suggested as the first representative of a separate chelonid PMV group, clustering with the two squamatid PMV groups into the proposed "Ferlavirus" genus (Kurath et al., 2004; Marschang et al., 2009). 
1 The results of a later publication (Papp et al., 2010a) characterizing 38 samples from

225 snakes, foreshadowed that all rPMV found in captive snake collections in

3 Germany belong to one of the two squamatid PMV groups. The current study based

4 on partial $\mathrm{L}, \mathrm{HN}$ and $\mathrm{U}$ gene sequences first describes a representative of a novel

5 third squamatid PMV cluster: "group C", equally distant from the other two squamatid

6 groups, within the proposed genus "Ferlavirus" genus (Fig. 1).

7 These interesting new findings underline the significance of sequencing in routine

8 reptilian virus diagnostics. It also shows the importance of testing for several different

9 pathogens. Although each of the viruses detected in these snakes has been reported

10 in connection with disease, the effect of combined infections and the prevalence of

11 such combined infections is unknown. Concentrating on a single pathogen (e.g. PMV

12 in snakes) can lead to underestimation of the importance of other infectious agents.

13 The case report also emphasizes the importance of disinfection together with entry

14 assessment prior to establishing new snake collections or introducing new animals

15 into formerly established groups.

16 
References

Ahne, W., Thomsen, I., Winton, J., 1987. Isolation of a reovirus from the snake, Python regius. Arch. Virol. 94, 135-139.

Ahne, W., Batts, W.N., Kurath, G., Winton, J.R., 1999. Comparative sequence analyses of sixteen reptilian paramyxoviruses. Virus Res. 63, 65-74.

Azevedo, I.L.M.J., Prieto da Silva, A.R.B., Carmona, E., Lee, Ho. P., 2001. Characterization of a paramyxovirus from a Fer de Lance Viper (Bothrops jararaca): partial nucleotide sequence of the putative fusion protein. Arch. Virol. 146, 51-57.

Bijlenga and Duclos, 1989. Isolation and plaque purification of a syncytial forming component of Myxoma virus. Microbiol. Infect. Dis. 12, 83-89.

Blahak, S., Göbel, T., 1991. A case reported of a reovirus infection in an emerald tree boa (Corallus caninus). In: Proceedings of the 4th International Colloquium on the Pathology of Reptiles and Amphibians, Bad Nauheim (Germany), pp. 13-16.

Blahak, S., 1995. Isolation and characterization of paramyxoviruses from snakes and their relationship to avian paramyxoviruses. J. Vet. Med. B. 42, 216-224.

Benkő, M., Kaján, G.L., Jánoska, M., Kovács, E.R., Wellehan, J.F.X., Zsivanovits, P., Cough, R.E., Blahak, S., Schirrmeier, H., Bakonyi, T., Harrach, B., 2006. How to find "new" adenoviruses. In: Leitão, A., Martins, C. (Eds.), Proceedings of the 7th International Congress of Veterinary Virology. Ministério da Agricultura, Lisboa, Portugal, pp. 103.

Bonfield, J.K., Smith, K.F., Staden, R., 1995. A new DNA sequence assembly program. Nucleic Acids Res. 24, 4992-4999.

Boom, R., Sol, C.J.A., Salimans, M.M.M., Jansen, C.L., Wertheim-Van Dillen, P.M. E., Van Der Noordaa, J., 1990. Rapid and simple Method for Purification of Nucleic Acid. J. Clin. Microbiol. 28, 495-503.

Clark, H.F., Lief, F.S., Lunger, P.D., Waters, D., Leloup, P., Foelsch, D.W., Wyler, R.W., 1979. Fer de Lance virus (FDLV): a probable paramyxovirus isolated from a reptile. J. Gen. Virol. 44, 405-418.

Daszak, P., Cunningham, A.A., Hyatt, A.D., 2000. Emerging infectious diseases of wildlife threats to biodiversity and human health. Science $287,443-449$.

Davison, A.J., Benkő, M., Harrach, B., 2003. Genetic content and evolution of adenoviruses. J. Gen. Virol. 84, 2895-2908.

Drury, S.E., Gough, R.E., Welchman, Dde, B., 2002. Isolation and identification of a reovirus from a lizard, Uromastyx hardwickii, in the United Kingdom. Vet. Rec. 151, 637-638.

Essbauer, S., Ahne, W., 2001. Viruses of lower vertebrates. J. Vet. Med. B, Infect. Dis. Vet. Public Health 48, 403-475. 
Farkas, S.L., Benkő, M., Élő, P., Ursu, K., Dán, A., Ahne, W., Harrah, B., 2002. Genomic and phylogenetic analyses of an adenovirus isolated from a corn snake (Elaphe guttata) imply a common origin with members of the proposed new genus Atadenovirus. J. Gen. Virol. 83, 2403-2410.

Farkas, S.L., Gál, J., 2009. Adenovirus and mycoplasma infection in an ornate box turtle (Terrapene ornata ornata) in Hungary. Vet. Microbiol. 138, 169-173.

Farkas, S.L., Harrah, B., Benkő, M., 2008. Completion of the genome analysis of snake adenovirus type 1 , a representative of the reptilian lineage within the novel genus Atadenovirus. Vir. Res. 132, 132-139.

Felsenstein, J., 1989. PHYLIP - Phylogeny Inference Package. Cladistics 5, 164-166.

Franke, J., Essbauer, S., Ahne, W., Blahak, S., 2001. Identification and molecular characterization of 18 paramyxoviruses isolated from snakes. Virus Res. 80, 67-74.

Frye, F.L., Munn, R.J., Gardner, M., Barten, S.L., Hardfy, L.B., 1994. Adenovirus-like hepatitis in a group of related Rankin's dragon lizards (Pogona henrylawsoni). J. Zoo. Wildl. Med. 25, 167-171.

Fölsch, D.W., Leloup, P., 1976. Fatale endemische Infektion in einem Serpentarium.Tierärztl. Praxis 4, 527-536.

Garner, M.M., Wellehan, J.F.X., Nordhausen, R.W., Barr, B., 2008. Characterization of enteric infections associated with two novel atadenoviruses in colubrid snakes. J. Herpetol. Med. Surg. 18, 86-94.

Hall, T.A., 1999. BioEdit: a user-friendly biological sequence alignment editor and analysis program for Windows 95/98/NT. Nucl. Acids. Symp. Ser. 41, 95-98.

Harrach, B., 2000. Reptile adenoviruses in cattle? Acta. Vet. Hung. 48, 484-490.

Heldstab, A., Bestetti, G., 1984. Virus associated gastrointestinal diseases in snakes. J. Zoo. An. Med. 15, 118-128.

Jacobson, E.R., 1986. Viruses and viral associated diseases of reptiles. Acta. Zool. Pathol. Antverp. 79, 73-90.

Jacobson, E.R., 1993. Implications of infectious diseases for captive propagation and introduction programs of threatened/endangered reptiles. J. Zoo. Wild. Med. 24, 245255.

Jacobson, E.R., 2007. Viruses and viral diseases of reptiles. In: Jacobson, E.R. (Ed.), Infectious Diseases and Pathology of Reptiles. Taylor and Francis, Boca Raton, pp. 395-460.

Jacobson, E.R., Gardiner, C.H., 1990. Adeno-like virus in esophageal and tracheal mucosa of a Jackson's chameleon (Chamaeleo jacksoni). Vet. Pathol. 27, 210-212. 
Juhász, A., Ahne, W., 1992. Physico-chemical properties and cytopathogenicity of an adenovirus-like agent isolated from corm snake (Elaphe guttata). Arch. Virol. 130, 429-439.

Junqueira de Azevedo, I. de L. M.; Prieto da Silva, Á. R. B.; Carmona, E., Lee, Ho.P., 2001. Characterization of a Paramyxovirus from a Fer de Lance viper (Bothrops jararaca): partial nucleotide sequence of the putative fusion protein. Arch. Virol. 146, 51-57.

Kindermann, J., Kübber-Heiss, A., Kerschbaumer, P., Nowotny, N., 2001. Phylogenetic analysis of the $\mathrm{L}$ and $\mathrm{HN}$ gene of ophidian paramyxoviruses. Arch. Virol. 146, 1021-1035.

Kurath, G., Batts, W.N., Ahne, W., Winton, J.R., 2004. Complete genome sequence of Fer-de-Lance virus reveals a novel gene in reptilian paramyxoviruses. J. Virol. 78, 2045-2056.

Kinsel, M.J., Barbiers, R.B., Manharth, A., Murnane, R.D., 1997. Small intestinal adeno-like virus in a mountain chameleon (Chameleo montium). J. Zoo. Wildl. Med. 28, 498-500.

Marschang, R.E., Donahoe, S., Manvell, R., Lemos-Espinal, J., 2002. Paramyxovirus and reovirus infections in wild-caught Mexican lizards (Xenosaurus and Abronia spp.). J. Zoo. Wildl. Med. 33, 317-321.

Marschang, R.E., Chitty, J., 2004. Infectious diseases. In: Girling, S.J., Raiti, P. (Eds.), Manual of Reptiles. British Small Animal Veterinary Association, Gloucester, pp. 330-345.

Marschang, R.E., Papp, T., 2010. Isolation and partial characterization of three reoviruses from lizards. J. Herpet. Med. Surg. 19, 13-15.

Marschang, R.E., Papp, T., Frost, J.W., 2009. Comparison of paramyxovirus isolates from snakes, lizards and a tortoise. Virus Res. 144, 272-279.

Ogawa, M., Ahne, W., Essbauer, S., 1992. Reptilian viruses: adenovirus like agent isolated from royal python (Python regius). J. Vet. Med. B. Infect. Dis. Vet. Public Health 39, 732-736.

Papp, T., Fledelius, B., Schmidt, V., Kaján, GL., Marschang, R.E., 2009a. PCRsequence characterization of new adenovirus found in reptiles and the first successful isolation of a lizards adenovirus. Vet. Microbiol. 134, 233-240.

Papp, T., Fledelius, B., Schmidt, V., Kaján, Gl., Romanova, I., Marschang, R.E., 2009b. New squamatid adenoviruses: partial PCR-sequence characterisation of the first lizard isolates together with other snake and lizard field samples. 8th Int. Congr. Vet. Virol., Budapest, Hungary, Aug. 23-26, pp. 82.

Papp, T., Pees, M., Schmidt, V., Marschang, R.E., 2010a. RT-PCR diagnosis followed by sequence characterization of paramyxovirus infections in clinical samples 
from snakes reveals concurrent infections within populations and/or individuals. Vet. Microbiol. 144, 466-472.

Papp, T., Seybold, J., Marschang, R.E., 2010b. Paramyxovirus infection in a leopard tortoise (Geochelone pardalis babcocki) with respiratory disease. J. Herpet. Med. Surg. (submitted for publication)

Pasmans, F., Blahak, S., Martel, A., Pantchev, N., 2008. Introducing reptiles into a captive collection: the role of the veterinarian. Vet. J. 175, 53-68.

Pees, M., Schmidt, V., Marschang, R. E., Heckers, K. O., Krautwald-Junghanns, M.E., 2010. Prevalence of viral infections in captive collections of boid snakes in Germany Vet. Rec. 166, 422-425.

Pénzes, J., Doszpoly, A., Harrach, B., Benkő, M., 2010. Further proofs for the reptilian origin of atadenoviruses. 8th Int. Symp. on Viruses of Lower Vertebrates, Santiago de Compostela, Spain, Apr. p. 26-28.

Ramis, A., Fernandez-Bellon, H., Majo, N., Martinez-Silvestre, A., Latimer, K., Campagnoli, R., Harmon, B.G., Gregory, C.R., Steffens, W.L., Clubb, S., Crane, M., 2000. Adenovirus hepatitis in a boa constrictor (Boa constrictor). J. Vet. Diagn. Invest. 12, 573-576.

Reed, L. J., Meunch, H., 1938. A simple method of estimating fifty percent endpoints. The American journal of hygiene 27, 493-497.

Rivera, S., Wellehan, J.F.X., McManamon, R., Innis, C.J., Garner, M.M., Raphael, B.L., Gregory, C.R., Latimer, K.S., Rodriguez, C.E., Diaz-Figueroa, O., Marlar, A.B., Nyaoke, A., Gates, A.E., Gilbert, K., Childress, A.L., Risatti, G.R., Frasca, S., 2009. Systemic adenovirus infection in Sulawesi tortoises (Indotestudo forsteni) caused by a novel siadenovirus. J. Vet. Diagn. Invest. 21, 415-26.

Richter, G.A., Homer, B.L., Moyer, S.A., Williams, D.S., Scherba, G., Tucker, S.J., Hall, B.J., Pedersen, J.C., Jacobson, E.R., 1996. Characterization of paramyxoviruses isolated from three snakes. Virus. Res. 43, 77-83.

Romanova, I., Marschang, R.E., Robert, N., Pees, M., Papp, T., 2011. Three novel snake atadenoviruses, proposed members of SnAdV-A species. (in preparation)

Schumacher, J., Jacobson, E.R., Burns, R., Tramontin, R.R., 1999. Adenovirus-like infection in two rosy boas (Lichanura trivirgata). J. Zoo. Wildl. Med. 25, 461-465.

Wellehan, J.F.X., Johnson, A.J., Harrach, B., Benkő, M., Pessier, A.P., Johnson, C.M., Garner, M.M., Childress, A., Jacobson, E.R., 2004. Detection and analysis of six lizard adenoviruses by consensus primer PCR provides further evidence of a reptilian origin for the atadenoviruses. J. Virol. 78, 13366-13369.

Wellehan, J.F.X., Childress, A.J., Marschang, R.E., Johnson, A.J., Lamirande, E.W., Roberts, J.E., Vickers, M.L., Gaskin, J.M., Jacobson, E.R., 2009. Consensus nested PCR amplification and sequencing of diverse reptilian, avian, and mammalian Orthoreoviruses. Vet. Mic. 133, 34-42. 


\section{Table legend}

3 Table 1. Virus positive corn snake samples.

4 Abbreviations: $\mathrm{AdV}=$ adenovirus, o/cl = oral \& cloacal, $\mathrm{PMV}=$ paramyxovirus, $\mathrm{Sn}=$ 5 snake.

6 *Virus isolation results summarized from $\mathrm{VH} 2$ and $\lg \mathrm{H} 2$ cells, viruses were

7 characterized based on the type of cytopathic effect (CPE), resistance to chloroform, 8 and (RT-)PCR and sequence verification.

9 \#For reoviruses, a $110 \mathrm{nt}$ long portion of the RNA-dependent RNA polymerase

10 (RDRP) gene was amplified and used for the sequence comparison (Wellehan et al., 11 2008). For $\mathrm{AdV}$, a 318 nt long portion of the DNA dependent DNA polymerase gene 12 was amplified and compared (Wellehan et al., 2004). For PMV, a 566 nt long portion 13 of the the RDRP gene (L-gene) was amplified in the diagnostic PCR (Ahne et al. 14 1999). That sequence, together with a $537 \mathrm{nt} \&$ a $648 \mathrm{nt}$ long portion of two further genes (the hemagglutinin-neuraminidase (HN-gene) \& the unique (U-gene)) were used for the seuquence comparison (Marschang et al., 2009). (All sizes are for the unedited PCR products.)

GenBank accession numbers: orthoreo isolate 55-02 (E4309703), snake AdV type 1

19 (DQ106414), SnAdV-1 like new type from 14/3/09 swab (HQ148088), snake AdV type 2 (FJ 012163),snake AdV type 3 (FJ 012164). Paramyxovirus PanGut-GER09 portions of L-, HN- \& U-genes (HQ148084 to HQ148087). 


\section{Figure legends}

3 Fig. 1 (a, b \& c). Phylogenetic distance trees of the reptilian PMV.

4 Sequences were analyzed using the PHYLIP program package (DNA distance

5 followed by FITCH). Bootstrap values over 60 from 100 resamplings of the FITCH

6 are indicated beside the nodes. Branches with lower values are drawn with

7 checkerboard lines.

8 Corresponding sequences (GenBank accession No.) from Newcastle disease virus 9 /NDV/ (AF375823), Sendai (NC_001552), and Human parainfluenza type 1 /HPIV-1/ 10 (AF457102) were used as outgroups. All other viruses on the trees are of reptilian 11 origin, mainly from snakes. Lizard and tortoise isolates are printed in italics and marked with one or two crosses respectively. The novel PMV isolate 'Pangut Ger 09' is marked in bold.

(a) Phylogenetic distance tree, based on 443 bp of the large RNA-dependent RNA polymerase (L) gene. GenBank accession numbers for the reptilian PMV: Bush viper virus /ATCC-VR-1409/ (AF286043), CeraCe-98 (AF351137), Crot-GER03 (GQ277611), CrotX1-96 (AF349405), Dasy-GER00 (GQ277613), ElaGut-91 (AF349408), Fer de Lance virus (NC_005084), GonoGER-85 (AF349404), IguGER00+ (GQ277617), Neotropical rattlesnake virus /ATCC-VR-1408/ (AF286045), Orth-GER05 (GQ277616), Pyth-GER01 (GQ277612), TORTOISE-GER99 ${ }^{++}$ (GQ277615), Xeno-USA99+ (GQ277614). For diagnostic non-isolated rPMV samples (Papp et al., 2010a): Pyt-2 kidney, Col-2c kidney, Pyt-6 intestine (GU393344 to GU393348). The following sequences (Ahne et al., 1999) were kindly provided by Dr. Gael Kurath and Dr. William N. Batts: Boa-CA98, Biti-CA98, Biti-GER 87, Call- 
1 GER88 ${ }^{+}$, Crot1-VA95, Crot2-OH90, Crot3-CA98, Ela1-GER94, Ela2-GER93, Ela-

2 FL93, Lamp-MD96, More-GER86, Pyth-GER88, Trim-MD97.

4 (b) Phylogenetic distance tree based on $351 \mathrm{bp}$ of the hemagglutinin-neuraminidase (HN) gene. The maximum likelihood analysis resulted in the same topology tree as the FITCH analysis, bootstrap values from both are indicated on the branches.

GenBank accession numbers: Bush viper virus /ATCC-VR-1409/ (AF286044), DasyGER00 (GQ277618), Fer de Lance virus (NC_005084), Igu-GER00 (GQ277619), NTV /ATCC-VR-1408/ (AF286046), Orth-GER05 (GQ277620), Xeno-USA99 ${ }^{+}$ (GQ277621). The other reptilian sequences (Ahne et al., 1999) were kindly provided 11 by Dr. Gael Kurath and Dr. William N. Batts.

(c) Phylogenetic distance tree of the reptilian PMV based on 568 bp of the unique (U) gene. Please note that no homologous sequence from non-reptilian PMV could be applied as an outgroup. The maximum likelihood analysis resulted in the same topology tree as the FITCH analysis, bootstrap values are both indicated on the branches. "Variant 1 and 2" represent the single nucleotide sequence variation of "Pangut Ger09" U gene sequence found in samples: 6/3/09, 14/2/09, 14/3/09, 14/11/09 and samples 14/6/09, 14/12/09 respectively.

GenBank accession numbers: Biti-CA98 (AY534645), Crot-GER03 (GQ277625),

Dasy-GER00 (GQ277627), Fer de Lance virus (NC_005084), Gono-GER85 (AY534644), Igu-GER00 ${ }^{+}$(GQ277623), Orth-GER05 (GQ277622), Pyth-GER01 (GQ277624), Xeno-USA99+ (GQ277626) 


\section{Table 1.}

\begin{tabular}{|c|c|c|c|c|c|c|c|c|c|}
\hline & \multirow[t]{2}{*}{ Lab. No. } & \multirow[t]{2}{*}{$\begin{array}{l}\text { Case history } \\
\text { (\& arrival date) }\end{array}$} & \multirow[t]{2}{*}{$\begin{array}{l}\text { Samples } \\
\text { tested }\end{array}$} & \multicolumn{3}{|c|}{$\begin{array}{l}\text { (RT-)PCR results of } \\
\text { field samples }{ }^{\#}\end{array}$} & \multirow{2}{*}{$\begin{array}{l}\text { Virus } \\
\text { isolation* }\end{array}$} & \multirow[t]{2}{*}{$\begin{array}{l}\text { Nucleotide identity of } \\
\text { partial gene sequences }\end{array}$} & \multirow[t]{2}{*}{ Comment } \\
\hline & & & & Reo & PMV & AdV & & & \\
\hline \multirow{2}{*}{$\begin{array}{l}\mathbf{G} \\
\mathbf{r} \\
\mathbf{o} \\
\mathbf{u} \\
\mathbf{p}\end{array}$} & $6 / 3 / 09$ & $\begin{array}{l}\text { A snake died in a } \\
\text { new collection. } \\
\text { (20-Jan-2009) }\end{array}$ & $\begin{array}{l}\text { lung } \\
\text { kidney } \\
\text { intestine }\end{array}$ & $\begin{array}{l}- \\
- \\
-\end{array}$ & $\begin{array}{l}- \\
+ \\
+\end{array}$ & $\begin{array}{l}- \\
+ \\
+\end{array}$ & $\begin{array}{l}\text { Reo } \\
\text { Reo, PMV } \\
\text { Reo, PMV, AdV }\end{array}$ & $\begin{array}{l}\text { Reo: } 100 \% \text { to orthoreo } 55-02 \\
\text { PMV:new type PanGut-GER09 } \\
\text { AdV: } 100 \% \text { to SnAdV-2 }\end{array}$ & \\
\hline & $\begin{array}{l}14 / 2 / 09 \\
14 / 3 / 09 \\
14 / 5 / 09 \\
14 / 6 / 09 \\
14 / 8 / 09 \\
14 / 10 / 09 \\
14 / 11 / 09 \\
14 / 12 / 09 \\
14 / 13 / 09\end{array}$ & $\begin{array}{l}\text { Swabs taken one } \\
\text { month later from } \\
13 \text { survivors of the } \\
\text { same group. } \\
\text { (26-Feb-2009) }\end{array}$ & $\begin{array}{l}\text { o/cl. swab } \\
\text { o/cl. swab } \\
\text { o/cl. swab } \\
\text { o/cl. swab } \\
\text { o/cl. swab } \\
\text { o/cl. swab } \\
\text { o/cl. swab } \\
\text { o/cl. swab } \\
\text { o/cl. swab }\end{array}$ & $\begin{array}{l}- \\
- \\
- \\
- \\
- \\
- \\
- \\
- \\
-\end{array}$ & $\begin{array}{l}+ \\
+ \\
- \\
+ \\
+\end{array}$ & $\begin{array}{l}+ \\
+ \\
- \\
- \\
- \\
- \\
- \\
- \\
-\end{array}$ & $\begin{array}{l}\text { Reo, PMV, AdV } \\
\text { Reo } \\
\text { Reo } \\
\text { Reo } \\
- \\
\text { Reo } \\
- \\
- \\
\text { Reo }\end{array}$ & $\begin{array}{l}\text { All had the same reo, } 100 \% \\
\text { identical to orthoreo isol. 55-02 } \\
\text { All had the same PMV, a new } \\
\text { type designated: PanGut-GER09 }\end{array}$ & $\begin{array}{l}\text { The other four snakes: } \\
\text { 14/1,14/4, } 14 / 7 \& 14 / 9 \\
\text { were tested negative } \\
\text { for the presence of } \\
\text { viruses. }\end{array}$ \\
\hline $\begin{array}{l}T \\
W \\
0\end{array}$ & $\begin{array}{l}54 / 1 / 09 \\
54 / 3 / 09 \\
54 / 4 / 09 \\
54 / 6 / 09\end{array}$ & $\begin{array}{l}1^{\text {st }} \text { group dispersed \& } \\
\text { new group } \\
\text { established. } \\
10 \text { animals tested. } \\
(10-J u l-2009)\end{array}$ & $\begin{array}{l}\text { o/cl. swab } \\
\text { o/cl. swab } \\
\text { o/cl. swab } \\
\text { o/cl. swab }\end{array}$ & $\begin{array}{l}- \\
- \\
-\end{array}$ & $\begin{array}{l}- \\
- \\
-\end{array}$ & $\begin{array}{l}+ \\
- \\
+ \\
+\end{array}$ & $\begin{array}{l}- \\
\text { Reo } \\
\text { Reo } \\
-\end{array}$ & $\begin{array}{l}\text { AdV: } 100 \% \text { to SnAdV-3 } \\
\text { Reo: } 100 \% \text { to orthoreo } 55-02 \\
\text { AdV: } 100 \% \text { to SnAdV-1 } \\
\text { AdV: } 100 \% \text { to SnAdV-2 }\end{array}$ & $\begin{array}{l}\text { The other six snakes: } \\
54 / 2,54 / 5 \& 54 / 7 \text { to } \\
54 / 10 \text { were negative in } \\
\text { virus detection tests. }\end{array}$ \\
\hline
\end{tabular}


Fig. 1/a

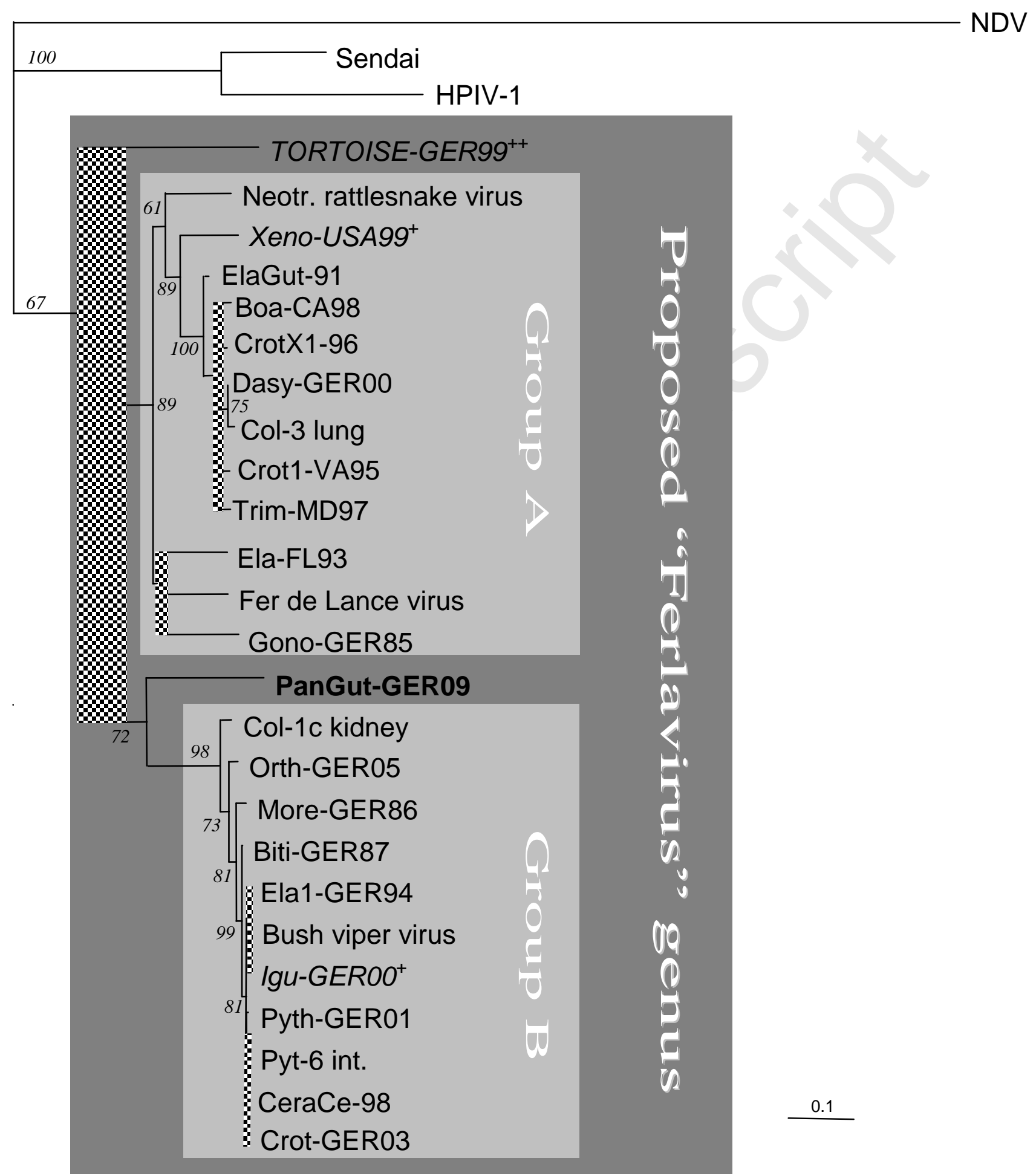


Fig. 1/b

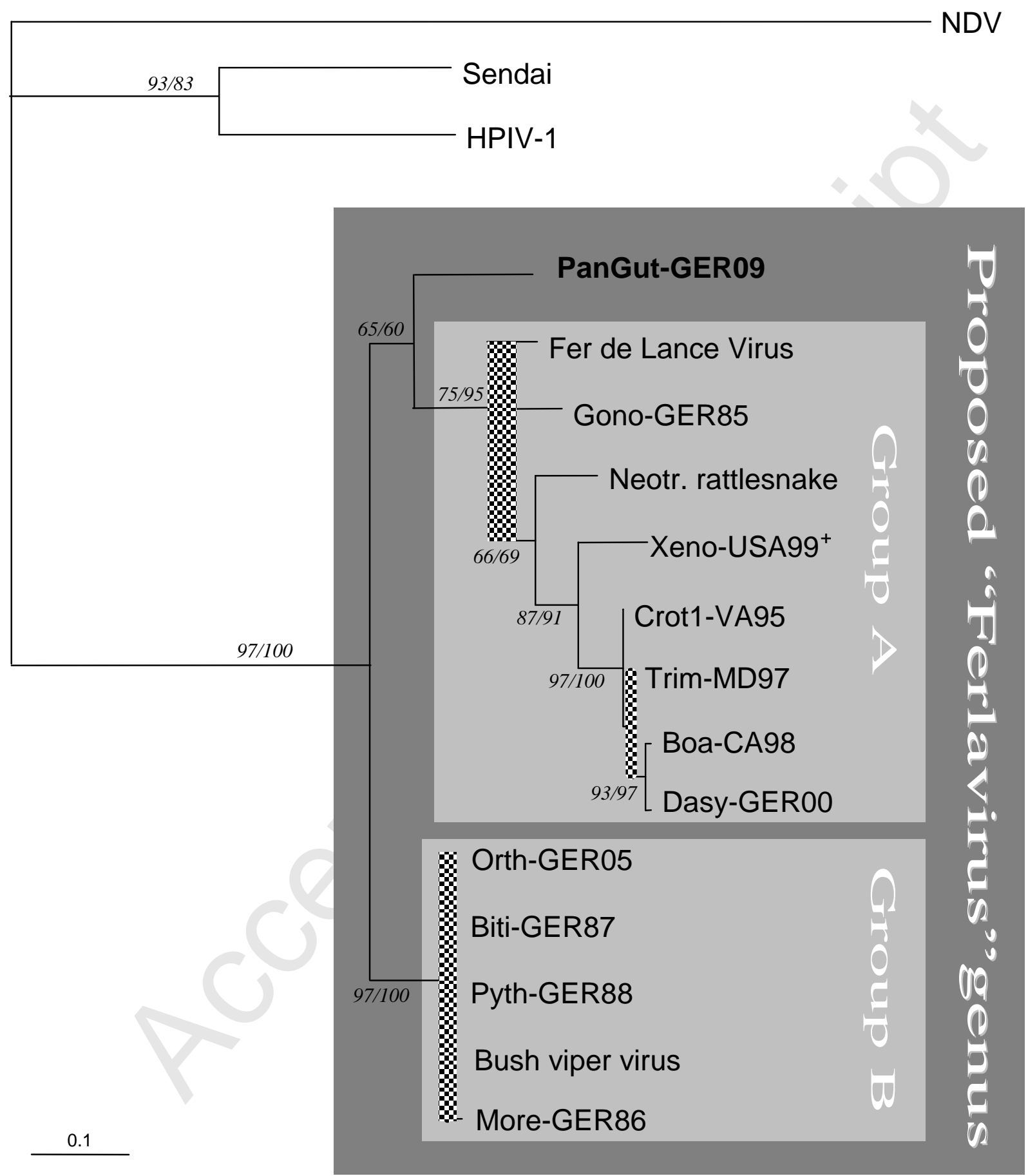


Fig. 1/C

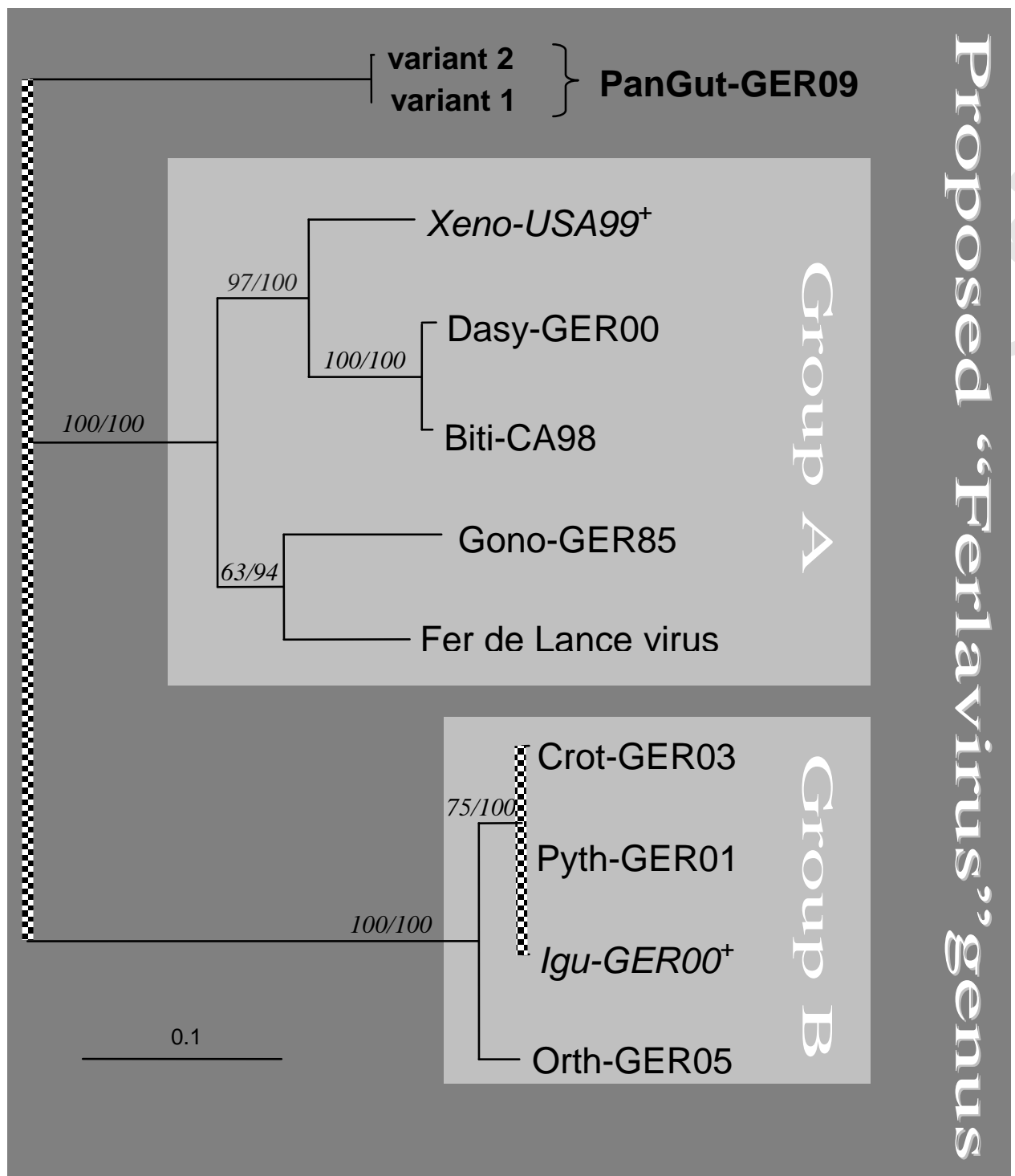

